THEORY AND PRACTICE

OF WEED CONTROL 


\section{Science in Horticulture Series}

General Editor: Professor L. Broadbent, University of Bath

Published in collaboration with the Royal Horticultural Society and the Horticultural Education Association

This series of texts has been designed for students on courses in horticulture at the Higher National Certificate or Diploma level, but care has been taken to ensure that they are neither too specialised for lower-level courses, nor too superficial for university work.

All the contributors to the series have had experience in both the horticultural industry and education. Consequently, the books have a strong practical flavour which should reinforce their value as textbooks and also make them of interest to a wide audience, including growers and farmers, extension officers, research workers and workers in the agrochemical, marketing and allied industries, and the many gardeners who are interested in the science behind their hobby.

The authors are all British but they have illustrated their books with examples drawn from many countries. As a result the text should be of value to English-speaking students of horticulture throughout the world. 


\title{
THEORY AND PRACTICE OF WEED CONTROL
}

\author{
R. J. STEPHENS \\ School of Biological Sciences \\ University of Bath
}


๑ R. J. Stephens 1982

All rights reserved. No part of this publication may

be reproduced or transmitted, in any form or by

any means, without permission.

First published 1982 by

THE MACMILLAN PRESS LTD

London and Basingstoke

Companies and representatives throughout the world

Typeset in Great Britain by

PINTAIL STUDIOS LTD

Ringwood, Hampshire

ISBN 978-0-333-21294-3

DOI $10.1007 / 978-1-349-86066-1$

ISBN 978-1-349-86066-1 (eBook)

The paperback edition of this book is sold subject to the condition that it shall not, by way of trade or otherwise, be lent, resold, hired out, or otherwise circulated without the publisher's prior consent in any form of binding or cover other than that in which it is published and without a similar condition including this condition being imposed on the subsequent purchaser 


\section{CONTENTS}

Preface

viii

1 EFFECTS OF WEED INFESTATION ON CROP YIELD AND QUALITY

1.1 What are weeds?

1.2 Losses in crop production due to weeds

1.3 Weed competition

1.4 Beneficial effects of weeds

1.5 Weeds as sources of pests and pathogens

2 THE ORIGINS, DISPERSAL AND CHARACTERISTICS

OF WEEDS

2.1 The origins of weeds

2.2 Distribution and spread of weeds

2.3 Special qualities of successful weeds

2.4 The changing weed flora

3 ONE YEAR'S SEEDS, SEVEN YEARS' WEEDS

3.1 Where weeds come from

3.2 Buried weed seeds in the soil

3.3 Propagation and survival of perennial weeds

3.4 One year's seeds, seven years' weeds

4 SPECIAL WEED PROBLEMS

4.1 Aquatic weeds

4.2 Poisonous plants

4.3 Parasitic weeds

4.4 Crops as weeds

4.5 Woody weeds

5 WEED CONTROL WITHOUT HERBICIDES

5.1 Integrated control

5.2 Cultivation

5.3 Flooding

5.4 Burning

5.5 Soil sterilisation

5.6 Mulching

5.7 Biological control 
6 HERBICIDES

6.1 Discovery and development of herbicides from antiquity to present times

6.2 Mode of action of herbicides

6.3 Testing and registration of new herbicides

6.4 Formulations, surfactants and additives

6.5 Herbicide resistance in weeds and crops

6.6 Behaviour of herbicides on plant surfaces

6.7 Fate of herbicides in plants: uptake, movement and metabolism

6.8 Herbicides in the soil: adsorption, metabolism and fate

7 HERBICIDE APPLICATION

7.1 Reaching the target

7.2 Spraying

7.3 Granules and their application

7.4 Government regulations and application

8 HERBICIDES AND CROP AND SOIL MANAGEMENT

8.1 Economic and social consequences of herbicide use

8.2 Management changes following weed control with herbicides

8.3 Potential energy savings when herbicides are used

8.4 Biological consequences of herbicide use

9 ROW CROPS GROWN AS ANNUALS OR BIENNIALS

9.1 Principles of weed control in row crops

9.2 Recent innovations in agronomy and weed control

9.3 Individual crop case studies

10 PERENNIAL CROPS OF ORCHARDS AND PLANTATIONS

10.1 Weed control strategies in perennial crops

10.2 Herbaceous temperate crops

10.3 Herbaceous tropical perennials - sugar cane and bananas

10.4 Woody plantation crops of the tropics and subtropics

10.5 Food and fruit crops of the tropics and subtropics

10.6 Temperate woody fruit crops

11 WEED CONTROL IN TURF, ORNAMENTALS AND FOREST TREES

11.1 Maintenance of lawns and urban turf

11.2 Maintenance of rough grass area

11.3 Production and maintenance of woodland and forest trees

11.4 Amenity tree and shrub production

11.5 Amenity tree and shrub plantings 
11.6 Bulbs and corms

11.7 Other herbaceous perennials

11.8 Total weed control

12 FUTURE DEVELOPMENTS IN WEED CONTROL

12.1 Background

12.2 Herbicide developments

12.3 Developments in application technology

12.4 Changes in crop agronomy

12.5 Weed control in the future

Index 


\section{PREFACE}

Why another book about weeds? Authors often begin by justifying a further addition to those already available, but there is such a dearth of books on weed science for students that no justification is required. This book is neither a comprehensive textbook nor a weed control manual but instead an attempt to provide an overall view of weed biology and control, illustrating the principles with appropriate examples drawn from temperate and tropical horticultural and plantation crops.

Wherever possible the vernacular and scientific plant names in the text are those recommended in J. G. Dony, F. Perring and Catherine M. Rob (1974), English Names of Wild Flowers, published by Butterworth for the Botanical Society of the British Isles. Tropical weeds and other species that do not appear in that list have been named according to the general practice in scientific journals and floras. Herbicides have been given the common names listed from time to time in Weed Science and Weed Research, and in those few cases where these lists do not agree the name given in Weed Research has been preferred. SI units of measurement are used throughout.

The references at the end of each chapter are intended to enable the reader to explore a particular interest more deeply. Most of those cited are modern and easily obtainable, but the older and historically interesting ones may only be obtainable from library loan services.

The author wishes to thank all those whose published works he has freely consulted during the preparation of this book. He also thanks the colleagues and friends who have read and commented upon parts of the book and especially Professor Leonard Broadbent who has patiently edited the whole book.

None of the information given in this book should be regarded as a recommendation, and anyone contemplating chemical weed control should follow directions given by the official advisory services in their region or by the manufacturers. 